\title{
Electrical Bioimpedance to Determine Body Composition in Students from the Colombian National Army's Training Schools
}

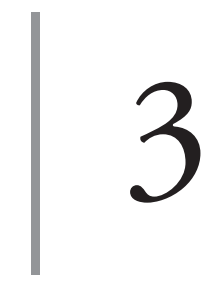

https://doi.org/10.21830/9789585380240.03

\author{
Jenner Cubides Amézquita ${ }^{l}$ \\ Esteban Aedo-Muñoz ${ }^{2}$ \\ Juan Camilo Mesa ${ }^{3}$ \\ CT. Iván Dario Chavarro Castañeda
}

\begin{abstract}
Determining the components of body composition is a necessity when evaluating the fitness of the Colombian military personel. Therefore, a cross-sectional observational study was proposed in which each of the body composition variables of students in the last level of military training was determined and compared. The study was carried out in three of the Colombian Army's schools where officers, non-commissioned officers, and professional soldiers are trained. The indirect method of electrical bioimpedance was used to measure body composition. The students' ages ranged from 18 to 25 years, with an average of $21 \pm 1.5$ years. Their average weight was $66.3 \pm 7.9 \mathrm{~kg}$, and their average body mass index was $23.2 \pm 2.16$ weight $\mathrm{kg} / \mathrm{height}^{2}$. The results showed a prevalence of $19.3 \%(n=26)$ overweight $(B M I \geq 25)$ in the sample; $80.1 \%(n=109)$ of the participants were of normal weight, according to $\mathrm{WHO}$ criteria. The Body Mass Index (BMI) was similar in students from the three training schools (ESMIC 23.65 $\pm 2.3 \mathrm{~kg} / \mathrm{m}^{2}$; EMSUB $23.41 \pm 2.4 \mathrm{~kg} / \mathrm{m}^{2}$; and ESPRO $22.57 \pm 1.4 \mathrm{~kg} / \mathrm{m}^{2}$ ). The absolute value of fat mass in the ESPRO students showed lower weight in fat than the

1 Medical Epidemiologist. RENFIMIL research group, Escuela Militar de Cadetes "General José María Córdova," Bogotá, Colombia.

$2 \mathrm{PhD}$. in Human Motor Sciences. Physical Activity, Sports, and Health Sciences Laboratory, Universidad de Santiago de Chile, USACH, Chile.

3 Nutritionist Dietician. Pontificia Universidad Javeriana, Bogotá, Colombia.

4 Artillery Officer of the Colombian Army. Director of the Research Center of Physical Culture (CICFI). Escuela Militar de Cadetes "General José María Córdova” Bogotá, Colombia.
\end{abstract}


ESMIC and EMSUB students (ESMIC $12.16 \pm 5.04 \mathrm{~kg}$; EMSUB $11.67 \pm 4.61 \mathrm{~kg}$; and ESPRO $9.20 \pm 4.07 \mathrm{~kg}$ ). Compared to Escuela Militar de Cadetes, the skeletal muscle mass presented variation in the two schools (ESMIC $28.52 \pm 2.79 \mathrm{~kg}$; EMSUB 25.82 $\pm 2.85 \mathrm{~kg}$; and ESPRO $26.83 \pm 2.88 \mathrm{~kg}$ ). The differences found in the students' body composition in the three schools were due to factors, like load, intensity, frequency, and training duration in each of the military institutions.

Keywords: body composition; electrical impedance; military personnel

\section{Introduction}

Military activities involve a series of specific tasks in different theatres of operation. Military personnel are exposed to environments and conditions considered stressors, including caloric deficit, sleep deprivation, altered moods, continuous physical activity, and even cases of fatigue (1)8, and 17, as well as the Workshop on Optimizing the Performance of Women in the Armed Forces of NATO, there remained open questions concerning mission-related testing and training. The Research and Technical Organization (RTO. Military operations require soldiers to have high levels of aerobic capacity, energy reserve, and muscular strength. Therefore, good fitness (aerobic resistance, muscular endurance, strength, flexibility, and body composition) and adequate physical conditioning, in general, are important "performance" factors and aid in preventing musculoskeletal injuries (2).

In Western countries, fitness and aerobic capacity have declined in young people over the last few decades. Obesity in both civilian and military personnel has increased. Physical activity is essential to improve fitness and prevent obesity (3). This phenomenon is a great challenge for current military training, where logistic and technological developments reduce certain physical activities (4). Obesity has increased globally. It is currently considered an epidemic with increased morbidity and mortality rates stemming from preventable health-related causes, followed by tobacco use. Prevention and strategies to control this pathology must be initiated from childhood and adolescence to avoid adult obesity. Adults who were obese during childhood have increased risk of morbidity and mortality regardless of their weight during adulthood (5). 
In the military field, the original intention of using variables, such as weight and height as parameters to decide on incorporating an individual with chronic malnutrition issues or inadequate weight for height has taken a radical turn. Currently, it focuses more on the prevention of overweight and obesity in the personnel to be incorporated. Now, the determinants of body composition are used to ensure acceptable physical abilities and rapid strength development through adequate nutrition and regular physical activity (6), in some cases, including predictors of strength performance (7). Although obesity in the military is, overall, below the average for the general population, inadequate body composition negatively impacts health care costs. It reinforces the need for policies and programs to reduce the prevalence of overweight and obesity (8).

Assessing body composition is an indispensable requirement to monitor obesity, nutritional status, training objectives, and general health (9)triceps, subsapular and supra-iliac - and total body density (by underwater weighing. In activities requiring the body mass to repeatedly overcome gravity during locomotion or jumping, excess adipose tissue acts as dead weight; this decreases military and sports performance and increases energy demand. On the other hand, fat-free mass contributes to energy production during high-intensity activities by improving absolute strength and resistance to static and dynamic loads (10). Components, like fat mass and fat-free (lean) mass are used to identify the body's nutritional requirements and energy expenditure (11). Sports nutrition experts use body composition data to develop specific dietary interventions and guide coaches and trainers to optimize and evaluate sports training programs.

Body composition assessment is frequently used in military fitness training to evaluate the effectiveness of programs for individuals considering weight loss or starting functional (strength, endurance, and body shape definition) or sports training (12). In the different training types, bodyweight control is one of the key problems during military and sports activities. Not surprisingly, some military personnel and athletes tend to increase and accelerate the training process; this can affect negatively health or performance 
in the field or competition. Therefore, technological efficiency in military and sports training systems must be improved, always through controlling processes that lead to optimizing the desired results.

In recent years, bioimpedance analysis (BIA) has been widely used in sports medicine. More and better methods to determine body structure and segments are being developed (13). Bioimpedance involves a flow of an alternating electric current of one or more radio frequencies transmitted by an electrode attached to the skin surface to characterize the tissues with or without good conduction, as well as the fluids that make up the body (14). Different speed current flows depend on the body's composition. Water is an excellent current conductor, as are tissues rich in electrolytes, such as muscle. Fatty tissue, bone, and pneumatic body spaces are poor current conductors (15).

We can briefly define some basic concepts to understand the fundamentals of bioimpedance. Impedance $(\mathrm{Z})$ is the frequency dependent on the opposition to the current flow by the conductor (e.g., the body). Geometrically, impedance is the vector composed of two frequency-dependent parameters (resistance $[\mathrm{R}]$ and reactance $\left[\mathrm{Xc}_{\mathrm{C}}\right.$ ). Resistance is the opposition to the current flow when passing through the body. Reactance is the delay in the electrical conduction caused by cell membranes, tissue interfaces, and non-ionic substances. Capacitance is a function of reactance that is increased when the cell membranes store a portion of the current for some time. This temporary storage of current charges creates a phase shift or phase angle $(\mathrm{PhA})$, quantified as the ratio of the arctangent of the reactance to the resistance expressed in degrees $\left(\mathrm{Xc}_{\mathrm{c}} / \mathrm{R}\right) \mathrm{x}\left(180^{\circ} / \pi\right)(15)$.

The $\mathrm{PhA}$ is a measure provided directly by bioimpedance equipment. It is used as a marker of cell membrane integrity and body cell mass, as well as a predictor of morbidity and mortality from chronic diseases, like renal failure (16) congestive heart failure (17), oncological pathologies (18), or malnutrition (19). The $\mathrm{PhA}$ is the ratio of the calculation between the resistance $(\mathrm{R})$ of the tissues to the passage of current (which depends on the state of hydration) and the reactance (Xc) of the tissues associated with cellularity, their size, and the cell membrane's integrity. 
A decreased $\mathrm{PhA}$ is consistent with cell death or an alteration in cell membrane selectivity. Increased $\mathrm{PhA}$ values are associated with the cell membrane and body mass integrity and vitality. In healthy populations, gender, age, and body mass index are the main $\mathrm{PhA}$ determinants (20). In these populations, the typical $\mathrm{PhA}$ ranges from $5^{\circ}$ to $7^{\circ}$. In athletes, the $\mathrm{PhA}$ can reach as high as $9.5^{\circ}$. There is very little literature on the determination of body composition by BIA concerning military training, less so in Colombia. Therefore, this study sought to make a general characterization of the bioelectric parameters of the body composition of students in the last level of training in the Colombian National Army's training schools.

\section{Methods}

The study's design was observational, descriptive, and transversal, with an analytical component in which BIA was used to evaluate the body composition of 135 students in the final level of military instruction. The study was carried out in three Colombian military training centers. The first was Escuela Militar de Cadetes "General José Maria Córdova" (ESMIC) in Bogotá, where National Army officers are trained. The second center was Escuela de Suboficiales "Sargento Inocencio Chinca" (EMSUB - Non-Commissioned Officers School) in Melgar, in the department of Tolima. The third was Escuela de Soldados Profesionales "Pedro Pascasio Martinez Rojas" (ESPRO - Professional Soldiers School) in the municipality of Nilo in Cundinamarca. This work was approved by the Social and Exact Sciences Ethics Committee (CECSE in Spanish) at Escuela Militar under Act 4363 REG-AL-FOL-71/02-2018. The study subjects participated in a meeting before beginning the data collection in which the study objectives and methodology were explained. They were provided all the information on the study and assured of the data's confidentiality with the signature of the informed consent. Participants remained anonymous, and withdrawal from the study had no consequences for their military career. 
The body composition variables were taken by an ISAK 1 (International Society for the Advancement of Kinanthropometry) nutritionist-anthropometrist, according to the "pre-test" protocol. Data collection was done in the morning, at the same time for all groups. The participants were weighed in their underwear and shoeless. Before the test, none had participated in physical exercise in the previous $24 \mathrm{~h}$ or eaten in the last $4 \mathrm{~h}$. They were all in good state of hydration, and their last urination was $30 \mathrm{~min}$ before the start of the tests. A SECA mBCA 525 Medical Body Composition Analyzer (Hans E. Ruth S.A, Hamburg, Germany) was used to measure body composition by electrical bio-impedance. We used the 8-point bio-electrical impedance analysis measurement method, with 19 measurement frequencies ranging from 1 to $1,000 \mathrm{kHz}$ and measuring values of impedance $(\mathrm{Z})$, resistance $(\mathrm{R})$, reactance $(\mathrm{Xc})$, and phase angle $(\Phi)$. The impedance measuring area of 10 $\Omega$ to $1,000 \Omega$ and current measurement of $100 \mu \mathrm{A}$ allowed multisegment recording of the body and phase angle $\left(0^{\circ}-20^{\circ}\right)$. Height was measured by using a hand-held platform stadiometer (Seca 274, Hamburg, Germany). Waist circumference was measured at the midpoint between the last rib and the iliac crest using a tape measure (Ohaus 8004-MA, Parsippany, MJ, USA). The data obtained were analyzed and stored by using Seca Analytics $115^{\circ}$ software.

\section{Statistical analysis}

Data were analyzed by determining central tendency (means and medians), dispersion (standard deviations, standard deviation absolute error, and upper and lower limit of 95\% confidence interval) measurements. Normal data distribution was assessed by using Kolmogorov-Smirnov tests. A one-factor variance (ANOVA) analysis with post hoc tests (Bonferroni and Games-Howell) for multiple comparisons was performed to determine differences among body composition variables in study participants at each training school, accounting for the assumptions for the test. Non-parametric statistics were used through the Kruskal Wallis test in the type of data that 
required it. The correlation between the sample's BMI and body composition variables was determined by using Spearman's test. The statistical software used in the data analysis was the Statistical Package for the Social Sciences V.24 (SPSS 24) and Graph Pad Prism 7 to diagram the results. The level of statistical significance was defined by a $95 \%$ confidence interval and the lowest probability value of $\mathrm{p} \leq 0.05$.

\section{Results}

The sample comprised 135 male cadets from the three Colombian Army's military training schools during the last level of military training (ESMIC - eighth semester, EMSUB - third semester of military training, and ESPRO - after six months of the basic military training phase). The students' ages ranged from 18 to 25 ( $21 \pm 1.5$ years). Their weight was 66.3 $\pm 7.9 \mathrm{~kg}$, and their average body mass index was $23.2 \pm 2.16$ height $^{2} /$ weight. Average height was $1.68 \pm 0.07 \mathrm{~m}$, and waist circumference for bioimpedance analysis yielded $0.786 \pm 0.056 \mathrm{~m}$. The prevalence of overweight (BMI $\geq 25)$ in the sample was $19.3 \%(\mathrm{n}=26) ; 80.1 \%(\mathrm{n}=109)$ of the participants were of average weight, according to $\mathrm{WHO}$ criteria. Once the analyses of body composition, anthropometric characteristics, and bioelectrical variables was performed, it was established that the BMI had similar values in the students from the three training schools (ESMIC $23.65 \pm 2.3 \mathrm{~kg} / \mathrm{m}^{2}$; EMSUB $23.41 \pm 2.4 \mathrm{~kg} / \mathrm{m}^{2} ;$ ESPRO $\left.22.57 \pm 1.4 \mathrm{~kg} / \mathrm{m}^{2}\right)$. The data obtained in fat mass absolute value showed that ESPRO students had a significantly lower volume of fat than the ESMIC and EMSUB students (ESMIC 12.16 $\pm 5.04 \mathrm{~kg}$; EMSUB $11.67 \pm 4.61 \mathrm{~kg}$; ESPRO $9.20 \pm 4.07 \mathrm{~kg}$ ). Similar values for fat-free mass were found in ESMIC and ESPRO. Meanwhile, the value was significantly lower for EMSUB (ESMIC $57.68 \pm 5.31 \mathrm{~kg}$; EMSUB $52.54 \pm 5.23 \mathrm{~kg}$; ESPRO $56.25 \pm 5.77 \mathrm{~kg}$ ). Compared to ESMIC, the skeletal muscle mass varied for the two other (ESMIC $28.52 \pm 2.79 \mathrm{~kg}$; EMSUB $25.82 \pm 2.85 \mathrm{~kg}$; ESPRO $26.83 \pm 2.88 \mathrm{~kg}$ ), reflected in the calculation of the kilocalories yielded by the individuals' total energy expenditure (ESMIC 
$3138.73 \pm 247.79 \mathrm{kcal}$; EMSUB $3018.05 \pm 207.87 \mathrm{kcal}$; ESPRO 3005.55 $\pm 164.74 \mathrm{kcal})$. Finally, in the $\mathrm{PhA}$ value analysis, EMSUB students had a lower PhA compared with the ESMIC and ESPRO students (ESMIC 7.78 $\pm 0.52^{\circ}$; EMSUB $7.56^{\circ} \pm 0.55^{\circ}$; ESPRO $\left.7.19^{\circ} \pm 0.66^{\circ}\right)$. However, they were considered outside the expected values for this young and physically active population (Table 1).

Table 1. Variables of body composition by bioimpedance of the students from the three National Army's training schools

\begin{tabular}{|c|c|c|c|c|c|c|}
\hline \multirow{2}{*}{$\begin{array}{c}\text { Variable } \\
\text { AGE (years) }\end{array}$} & \multicolumn{2}{|c|}{$\begin{array}{c}\text { ESMIC } \\
\text { x sd }\end{array}$} & \multicolumn{2}{|c|}{$\begin{array}{c}\text { EMSUB } \\
\text { x sd }\end{array}$} & \multicolumn{2}{|c|}{$\begin{array}{c}\text { ESPRO } \\
\text { x sd }\end{array}$} \\
\hline & 22.58 & 1.234 & 21.38 & 1.775 & 21.24 & 1.26 \\
\hline WEIGHT (kg) & 69.846 & 8.667 & 64.220 & 7.7595 & 64.9244 & 6.0784 \\
\hline SIZE (m) & 1.7173 & .06340 & 1.6553 & .06244 & 1.6953 & .07288 \\
\hline BMI $\left(\mathrm{kg} / \mathrm{m}^{2}\right)$ & 23.651 & 2.3576 & 23.411 & 2.4618 & 22.578 & 1.34137 \\
\hline $\begin{array}{l}\text { WAIST CIRCUM- } \\
\text { FERENCE }(\mathrm{cm})\end{array}$ & 0.8078 & 0.0613 & 0.7902 & 0.0594 & 0.7609 & 0.0346 \\
\hline FAT MASS (kg) & 12.1633 & 5.04370 & 11.6736 & 4.6163 & 8.6667 & 2.5304 \\
\hline $\begin{array}{l}\text { FAT-FREE MASS } \\
(\mathrm{kg})\end{array}$ & 57.6833 & 5.3164 & 52.5464 & 5.2335 & 56.2578 & 5.7722 \\
\hline $\begin{array}{l}\text { SKELETAL } \\
\text { MUSCLE }(\mathrm{kg})\end{array}$ & 28.5216 & 2.7909 & 25.8207 & 2.8538 & 26.8389 & 2.8802 \\
\hline $\begin{array}{l}\text { TOTAL BODY } \\
\text { WATER }(\mathrm{kg})\end{array}$ & 41.8756 & 4.0355 & 38.0689 & 3.9346 & 40.8978 & 4.3203 \\
\hline $\begin{array}{l}\text { EXTRACELL } \\
\text { FLUID }(\mathrm{kg})\end{array}$ & 16.3311 & 1.8115 & 15.1467 & 1.7238 & 16.6756 & 2.0061 \\
\hline $\begin{array}{l}\text { ENERGY } \\
\text { EXPENDITURE } \\
\text { (Kcal) }\end{array}$ & 3138.73 & 247.791 & 3018.05 & 207.875 & 3005.55 & 164.746 \\
\hline $\begin{array}{l}\text { RESPONSE } \\
\text { EXPENDITURE } \\
\text { (Kcal) }\end{array}$ & 1739.83 & 130.337 & 1657.24 & 114.965 & 1669.75 & 91.526 \\
\hline ANGLE (o) & 7.78 & .522 & 7.56 & .553 & 7.19 & .6643 \\
\hline
\end{tabular}

* Median (x) and standard deviations(sd); Escuela Militar de Cadetes "General José María Córdoba" (ESMIC); Escuela de suboficiales "Sargento Inocencio Chinca" (EMSUB); Escuela de Soldado Profesionales "Pedro Pascasio Martínez Rojas" (ESPRO).

Source: Material created by the authors. 
In the subsequent set of figures, the comparisons of some of the body composition variables for the three schools are presented. For the multiple comparisons, a one-factor analysis of variance (ANOVA) was perfomed with Bonferroni or Games Howell tests, as the case may be, for data with normality in its distribution. An Inter-group comparison was also performed for data with non-parametric distribution using the Kruskal Wallis statistician. Statistically significant differences were found in the BMI between ESMIC and ESPRO ( $p=0.029$ ) (Figure 1). Figure 2 shows the statistically significant differences in fat mass between ESMIC and ESPRO $(p=0.0001)$, and between EMSUB and ESPRO $(p=0.001)$. Figure 4 shows differences in skeletal muscle mass between ESMIC and EMSUB ( $p=0.0001)$, and between ESMIC and ESPRO ( $p=0.0001)$. Figure 3 shows the fat-free mass comparison between ESMIC and EMSUB $(p=0.0001)$, and between EMSUB and ESPRO $(p=0.005)$. Figure 6 shows the total energy expenditure between ESMIC and EMSUB ( $p=0.021)$, and between ESMIC and ESPRO $(p=0.009)$. Figure 4 shows the PhA statistically significant differences between ESMIC and EMSUB $(p=0.0001)$, and between EMSUB and ESPRO $(p=0.009)$. Figure 5 shows the comparison of total body water between ESMIC and EMSUB ( $\mathrm{p}=0.0001)$, and BETWEEN EMSUB and ESPRO $(\mathrm{P}=0.0004)$. Figure 7 shows the comparison of the phase angle between ESMIC and EMSUB students ( $\mathrm{p}=0.0001)$, and between EMSUB and ESPRO students $(\mathrm{p}=0.009)$. Figure 8 presents the correlation analysis between BMI and bioelectrical variables, which showed a significant relationship with the fat mass value $(r=0.83 ; p=0.0001)$, and the skeletal muscle mass $(r=0.45 ; p=0.0001)$ (Figure 9). 


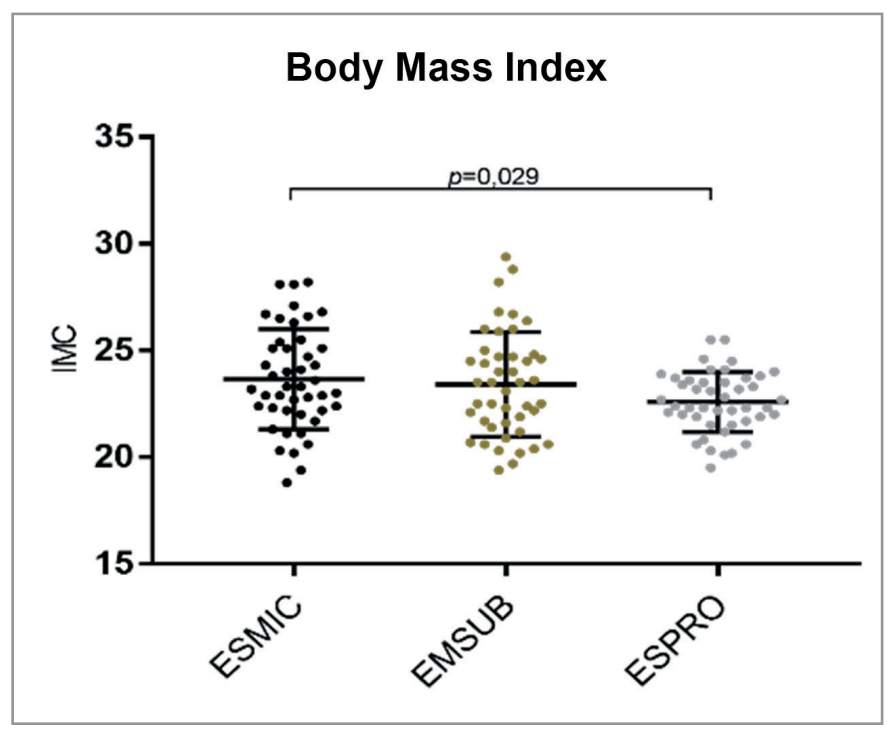

Figure 1. Comparison in the Body Mass Index among the students of the three schools (Games-Howell test).

Source: material created by the authors.

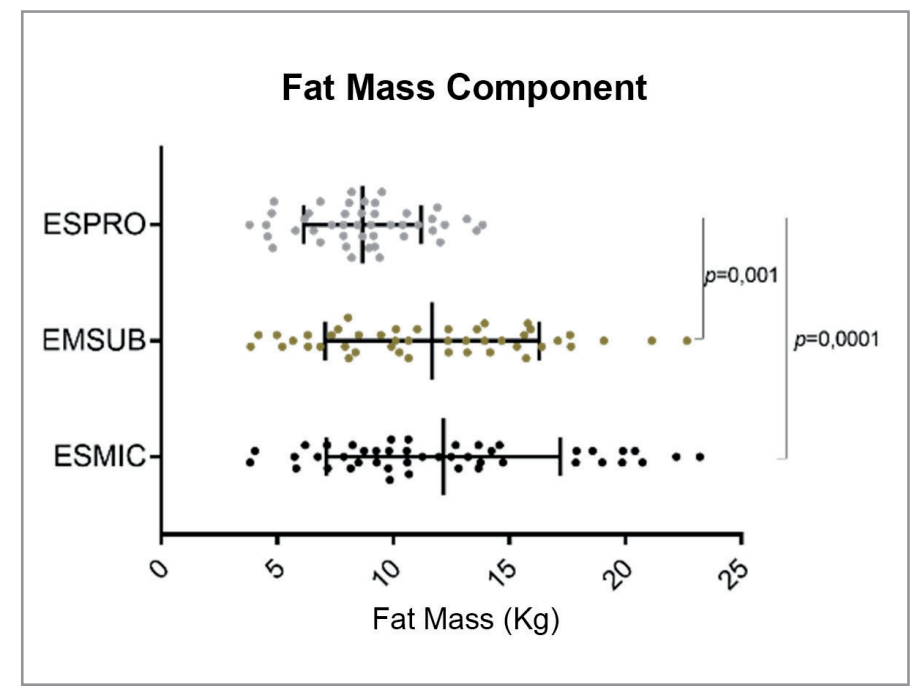

Figure 2. Comparison of the fat mass component among the students of the three schools (Games-Howell test)

Source: material created by the authors. 


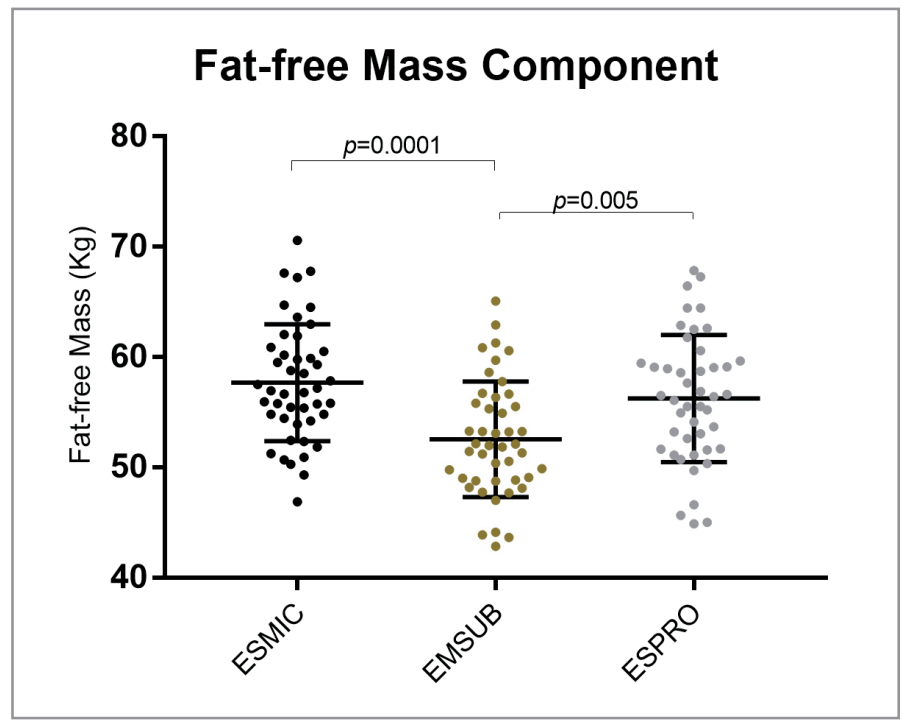

Figure 3. Comparison of the Fat-free Mass component among students in the three schools (Bonferroni test).

Source: material created by the authors.

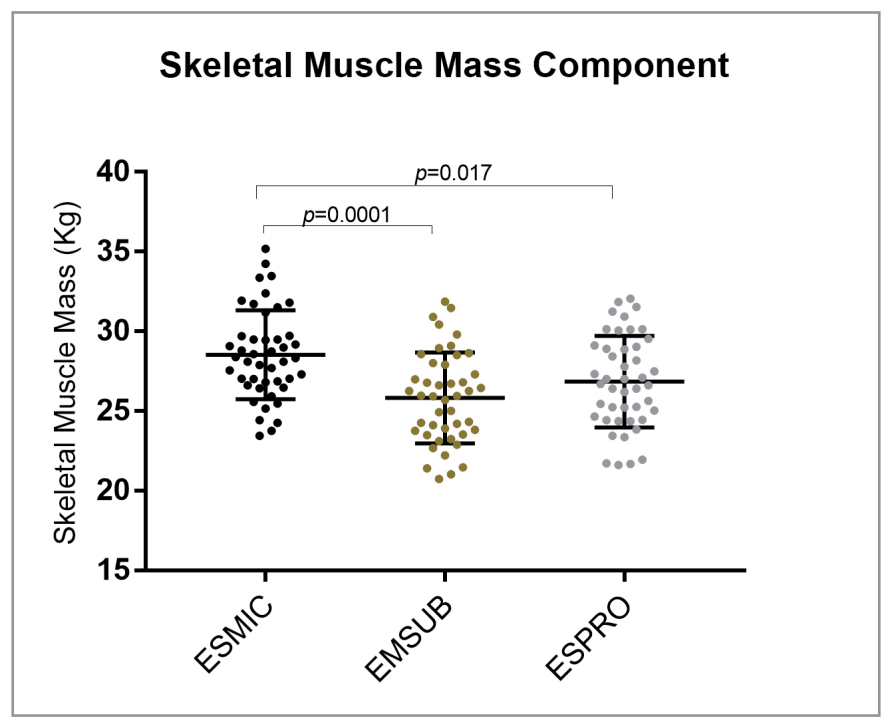

Figure 4. Comparison of the Skeletal Muscle Mass component among the students of the three schools (Bonferroni test)

Source: material created by the authors. 


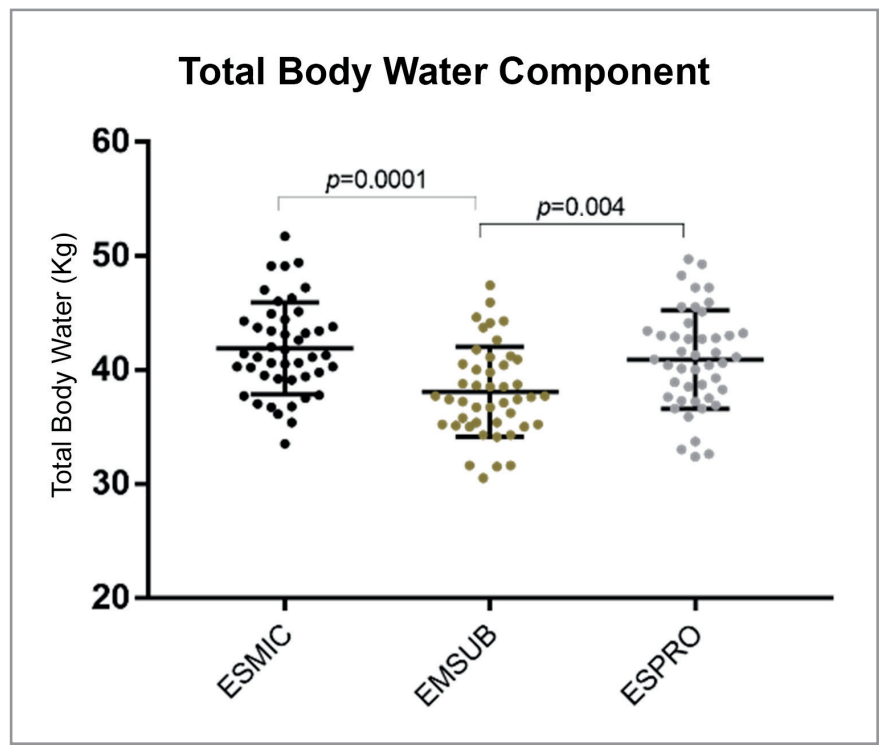

Figure 5. Comparison of the Total Body Water component (hydration status) among the students of the three schools (Bonferroni test)

Source: material created by the authors.

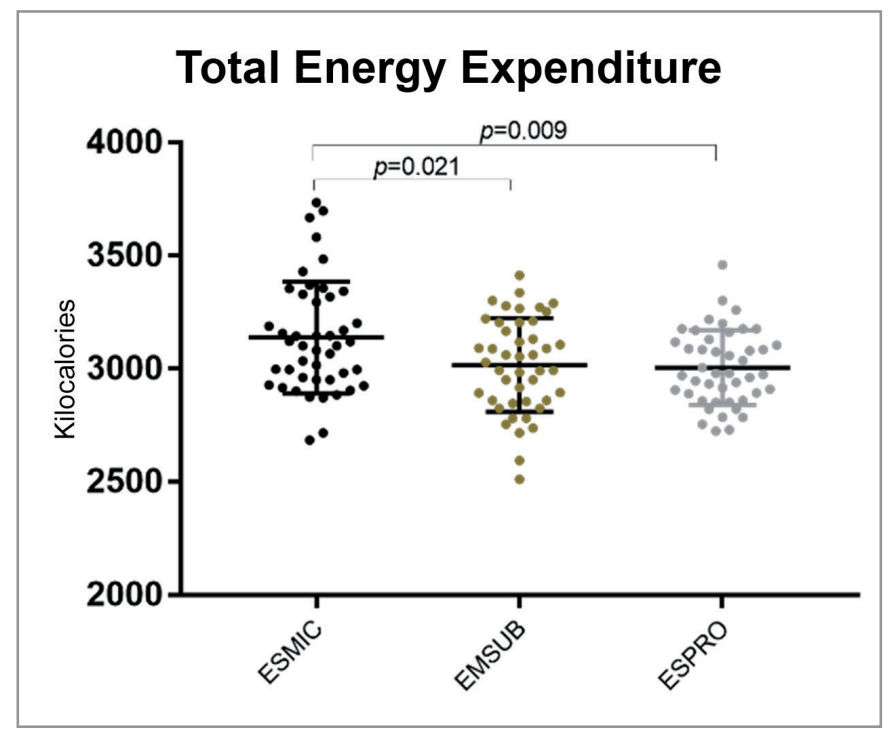

Figure 6. Comparison in the prediction of the total energy expenditure among the students of the three schools (Bonferroni test)

Source: material created by the authors. 


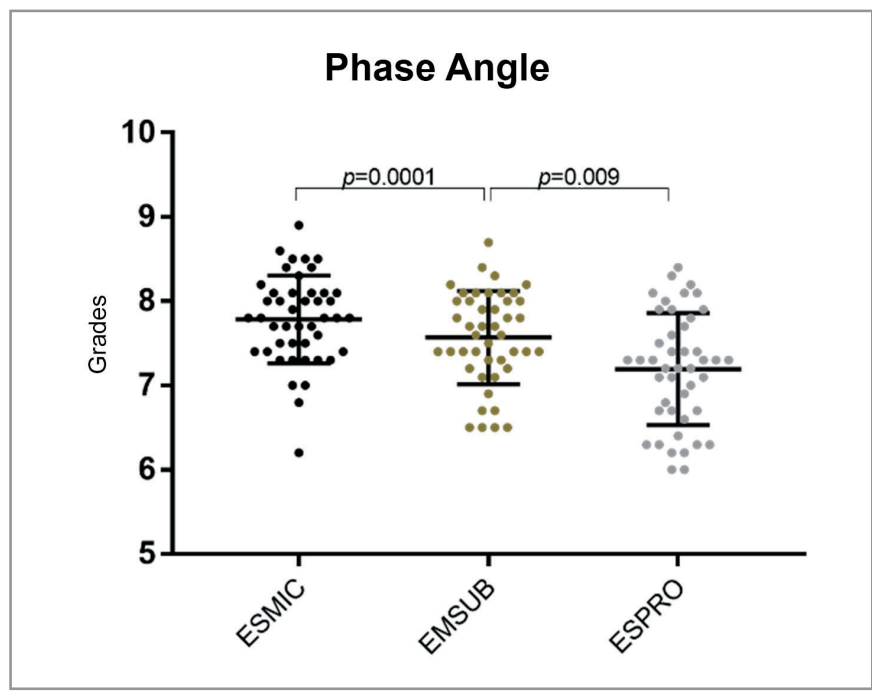

Figure 7. Comparison of the phase angle between the students of the three schools (Bonferroni test)

Source: Material created by the authors.

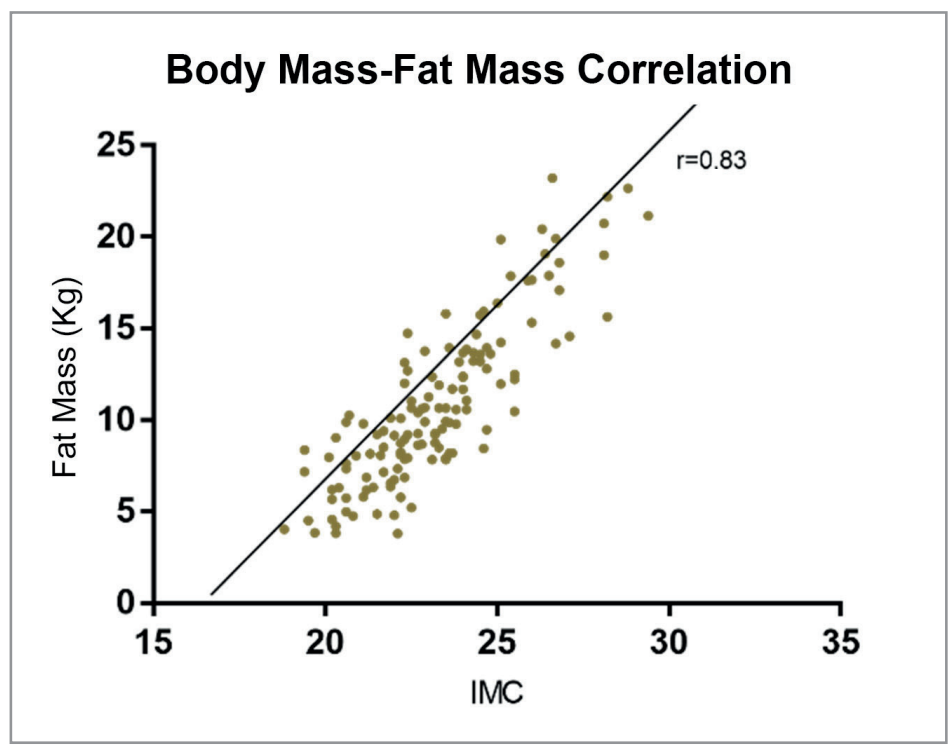

Figure 8. Correlation between Body Mass Index (BMI) and Fat Mass of study participants (Spearman's test).

Source: material created by the authors. 


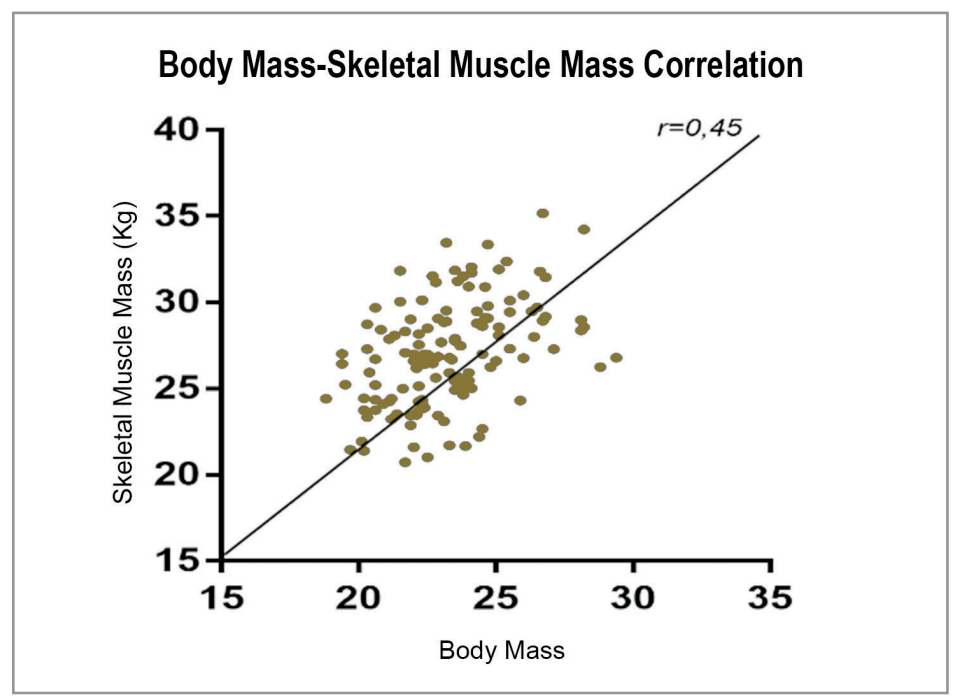

Figure 9. Correlation between Body Mass Index (BMI) and Skeletal Muscle Mass of study participants (Spearman's test).

Source: material created by the authors.

\section{Discussion}

Maintaining adequate levels of fitness and body composition in military personnel has been a selection criterion for carrying out tasks typical of the physical demands of military service, assuming that adequate body weight is synonymous with good health, adequate physical and mental condition, and suitable military appearance (21) Advances in health services, technological and computer developments, and improved nutritional requirements in recent decades have led to an increase in the general population's average weight, height, and fat-free mass. However, excessive consumption of food quantity and quality and physical inactivity cause risks of overweight issues that impact military health and performance. One of the most relevant questions by the organizations in charge of evaluating physical training and military plans is how to evaluate the physical performance (fitness) of its members. Four components have been proposed in the evaluation, i.e., aerobic capacity, muscular power, resistance, and body composition (22). 
The body composition of military personnel undergoing technical and tactical training in the Colombian National Army's training schools had not been previously characterized comprehensively. This work allowed contrasting this description with studies abroad and among the three schools.

The BMI, which is an indicator of population screening for overweight and obesity using weight-for-height analysis, in the entire sample for this study was $23.21 \pm 2.16 \mathrm{~kg} /$ height $^{2}$. In 2017, Maldonado et al., found similar BMI values of $22.7 \pm 2.7$ weight $\mathrm{kg} /$ height $^{2}$ in a study of 153 students at an army soldier training school in Ecuador. However, the body composition data were obtained via skin folds (23) Another study by Cortés et al., (2017) of military personnel in Colombia determined BMI values of $24.4 \pm 2.22$ weight $\mathrm{kg} / \mathrm{length}^{2}$ in 72 cadets attending a 12-week combat course. These values were collected through electrical bioimpedance prior to the combat course training (24). In 2016, a study by Duran-Agüero et al., found BMI values in military men under 30 years of age of $25.4 \pm 2.9$ weight $\mathrm{kg} / \mathrm{height}^{2}$ in a sample of 415 soldiers of a Chilean military parachute brigade (25). Gómez et al., (2016) used bioimpedance to determine a BMI of $26.90 \pm$ 0.80 weight $\mathrm{kg} / \mathrm{height}^{2}$ for 288 Mexican service personnel (26). In a study conducted in the United Kingdom, during the Gulf War, Blacker et al., (2011) evaluated different parameters in 119 members from different military forces (Navy, Air Force, and Army), finding a BMI of 22.2 \pm 2.6 weight $\mathrm{kg} /$ height $^{2}$ (27). Overall, the average BMI in the different armies evaluated did not show major differences, except for the study in Chile assessing subjects over 25 years of age, which is related to increased BMI associated with age.

In this study, in the three Colombian Army's training schools, significant differences were found in BMI between the students from Escuela Militar de Cadetes (ESMIC) and those from Escuela de Soldados Profesionales (ESPRO). These differences are closely related with lower values in the fat mass component of the ESPRO soldiers, which is explained by several reasons. The first reason is the intensity of a shorter training program (12 weeks of constant training and field equipment load). The second is altitude; 
training occurs at 336 meters above sea level, whereas Bogotá is at 2600 masl. Given its location, sensible and insensible fluid losses are higher at ESPRO; this affects the weight assessment and fat mass component, making it lower in this population, which directly influences a lower BMI.

This study's fat mass component was estimated at $10.83 \pm 4.45 \mathrm{~kg}$. These results are similar to those in studies by Cortés et al., (2018) who found values of $6.27 \pm 4.88 \mathrm{~kg}$, Duran-Agüero et al., (2017) in Chile, where the fat mass values were $16.1 \pm 5.6 \mathrm{~kg}$ and Vásquez Guzmán et al., (2016) in Mexico who reported values of $19.32 \pm 3.07 \mathrm{~kg}$. When observing the latter populations, higher BMI values could be attributed to increased fat mass, age-related overweight issues, and low physical activity levels. In our comparison of the three schools, ESPRO showed lower fat mass values than the other two Army training schools.

The average fat-free mass component for the three schools was $55.49 \pm$ $5.82 \mathrm{~kg}$. In a previous study by Cortés et al., (2017) values of $66.3 \pm 6.12 \mathrm{~kg}$ were found for their sample of Colombian military personnel. Meanwhile, in Chilean military personnel, the fat-free mass was $57.8 \pm 6.0 \mathrm{~kg}$. Finally, in the Mexican military population, this value was estimated at $57.55 \pm 5.09$ $\mathrm{kg}$. In our comparison of the training schools, significant differences were found in the fat-free mass values. The group at EMSUB had the lowest component of fat-free tissue.

No strong correlation was found between BMI and fat mass $(r=0.33$; $p=0.001)$. These values were similar to those obtained in the Mexican military population $(r=0.33)$ and very different from the correlation of the Chilean population's components $(r=0.61)$. Regarding the average skeletal muscle mass component in this study's population, it was $27.06 \pm 3.03 \mathrm{~kg}$. These values were unlike those reported by Cortés et al., (2017) in a similar population, where the value of skeletal muscle mass was $63 \pm 5.09 \mathrm{~kg}$. Based on the comparison, the EMSUB military personnel had lower skeletal muscle component. Significant differences were found between the military personnel at ESMIC and at ESPRO. The correlation obtained between BMI and skeletal muscle mass was positive between these two variables $(p=0.45)$. 
Although values were obtained in this study for body composition variables, such as total energy expenditure, energy expenditure at rest, total body water, extracellular fluid, and phase angle, no military-related literature was found to contrast them. However, having a baseline of the bioelectrical characteristics of body composition is essential to describe this population, given that, when comparing the results obtained in the three schools, significant differences were found, which could be explained in terms of training times, intensity, and frequency. However, in general terms, they do not present alterations regarding the standards determined in other studies for a military population.

\section{Conclusions}

Although very few studies exist of body composition analysis by electrical bioimpedance in young people, and more so in a military population, this work determined the body composition variables most commonly used in sports nutrition and military training. This pilot study showed specific statistical differences in body composition components and bioelectrical variables according to the training school. Although the sample is homogeneous, we can evidence that ESPRO has a lower percentage of fat mass than ESMIC and EMSUB, which could be explained by the intensive and continuous training process during the four months of the instruction phase. Moreover, the skeletal muscle mass was higher for ESMIC and ESPRO than for EMSUB. This study is a first step to studies that will allow better characterizing the variables of interest with more representative samples of all the National Army's units.

\section{Acknowledgments}

We thank the directors and staff at Escuela Militar de Cadetes "General José María Córdova”, Escuela de Suboficiales "Sargento Inocencio Chincá," and Escuela de Soldados Profesionales "Pedro Pascasio Martínez Rojas" for 
their unconditional support in the development of this study. The authors declare having no conflict of interest in the development of this study.

\section{Funding}

This study was carried out with resources from the internal call 001-2017 by the Colombian Army Technological Support Command according to Act 65060 of 05 July 2017.

\section{References}

1. Task Group 019. Report RTOT. Optimizing Operational Physical Fitness Optimisation de l' aptitude physique opérationnelle ). Vol. 323. 2009. 342 p.

2. Santtila M, Keijo H, Laura K, Heikki K. Changes in cardiovascular performance during an 8-week military basic training period combined with added endurance or strength training. Mil Med. 2008;173(12):1173-9.

3. Haskell WL, Lee IM, Pate RR, Powell KE, Blair SN, Franklin BA, et al. Physical activity and public health: Updated recommendation for adults from the American College of Sports Medicine and the American Heart Association. Med Sci Sports Exerc. 2007;39(8):1423-34.

4. Cawley J, Maclean JC. Unfit for Service: The Implications of Rising Obesity for U.S. Military Recruitment. 2010; Available from: http://www.nber.org/papers/w16408

5. Shi H, Jiang B, Wei Sim JD, Chum ZZ, Ali N Bin, Toh MH. Factors Associated With Obesity: A Case-Control Study of Young Adult Singaporean Males. Mil Med [Internet]. 2014;179(10):1158-65. Available from: https://academic.oup.com/ milmed/article/179/10/1158-1165/4159654

6. Pihlainen Kai, Santtila Matti, Hakkinen Keiji KH. Associations of physical Fitness and Body Composition Characteristics with Simulated Military Task Performance. J Strength Cond Res. 2018;32(4):1089-98.

7. Bahamondes-Avila C, Cárcamo-Oyarzún J, Aedo-Muñoz E, Rosas-Mancilla M. Relación entre indicadores antropométricos regionales de masa muscular y potencia de extremidades inferiores en deportistas juveniles de proyección. Rev Bras Ciências do Esporte. 2018;40(3):295-301.

8. Pierce JR, DeGroot DW, Grier TL, Hauret KG, Nindl BC, East WB, et al. Body mass index predicts selected physical fitness attributes but is not associated with perfor- 
mance on military relevant tasks in U.S. Army Soldiers. J Sci Med Sport [Internet]. 2017;20(2017):S79-84. Available from: https://doi.org/10.1016/j.jsams.2017.08.021

9. Durnin BYJVG a, Womersley J. and Its Estimation From Skinfold Thickness: Measurements on. Br J Nutr [Internet]. 1973;32(1):77-97. Available from: http:// www.ncbi.nlm.nih.gov/pubmed/4843734

10. Mala L, Maly T, Zahalka F, Bunc V, Kaplan A, Jebavy R, et al. Body composition of elite female players in five different sports games. J Hum Kinet. 2015;45(1):207-15.

11. Nelson KM, Weinsier RL, Long CL, Schutz Y. Prediction of resting energy expenditure from fat-free mass and fat mass. Am J Clin Nutr [Internet]. 1992 Nov 1 [cited 2017 Oct 23];56(5):848-56. Available from: http://www.ncbi.nlm.nih.gov/pubmed/1415003

12. Ickerson BRSN, Sco MIRE, Liszczewicz BRMK. Comparison of Bioimpedance and Underwater Weighing Body Fat Percentage Before and Acutely After Exercise at Varying Intensities. J Strength Cond Res. 2016;31(5):1395-402.

13. Dopsaj M, Markovic M, Kasum G, Jovanovic S, Koropanovski N, Vukovic M, et al. Discrimination of Different Body Structure Indexes of Elite Athletes in Combat Sports Measured by Multi Frequency Bioimpedance Method. 2017;35(1):199-207.

14. Portao J, Bescós R, Irurtia A, Cacciatori E, Vallejo L. Valoración de la grasa corporal en jóvenes físicamente activos: Antropometría vs bioimpedancia. Nutr Hosp. 2009;24(5):529-34.

15. Mulasi U, Kuchnia AJ, Cole AJ, Earthman CP. Bioimpedance at the bedside: Current applications, limitations, and opportunities. Nutr Clin Pract. 2015;30(2):180-93.

16. Caravaca F, del Viejo CM, Villa J, Gallardo RM, Ferreira F. Estimación del estado de hidratación mediante bioimpedancia espectroscópica multifrecuencia en la enfermedad renal crónica avanzada. Nefrologia. 2011;31(5):537-44.

17. Colín-Ramírez E, Castillo-Martínez L, Orea-Tejeda A, Vázquez-Durán M, Rodríguez $\mathrm{AE}$, Keirns-Davis C. Bioelectrical impedance phase angle as a prognostic marker in chronic heart failure. Nutrition. 2012;28(9):901-5.

18. Gupta D, Lammersfeld CA, Vashi PG, King J, Dahlk SL, Grutsch JF, et al. Bioelectrical impedance phase angle as a prognostic indicator in breast cancer. BMC Cancer [Internet]. 2008;8(1):249. Available from: http://bmccancer.biomedcentral.com/articles/10.1186/1471-2407-8-249

19. Urbain P, Birlinger J, Ihorst G, Biesalski H-K, Finke J, Bertz H. Body mass index and bioelectrical impedance phase angle as potentially modifiable nutritional markers are independent risk factors for outcome in allogeneic hematopoietic cell transplantation. Ann Hematol [Internet]. 2013;92(1):111-9. Available from: http://link.springer. $\mathrm{com} / 10.1007 / \mathrm{s} 00277-012-1573-4$

20. Barrea L, Muscogiuri G, Macchia PE, Di Somma C, Falco A, Savanelli MC, et al. Mediterranean diet and phase angle in a sample of adult population: Results of a pilot study. Nutrients. 2017;9(2):1-14. 
21. Naghii MR. The Importance of Body Weight and Weight Management for Military Personnel. Mil Med. 2015;171(6):550-5.

22. Sackett P, Anne: M. Physical Fitness and Musculoskeletal Injury. In: Assessing Fitmness for Military Enlistment: Physical, Medical and Mental Health Standards. 2005. p. 66-108.

23. Maldonado I; SC. Perfil antropométrico y composición corporal en aspirantes de la escuela de formación de soldados del ejército / Anthropometric profile and body composition in applicants of Training... Rev Cuba Investig Biomédicas. 2018;36 (January 2017):1-15.

24. Cortés Fernández S, Camargo IY, Botero Rosas D. Modificaciones en el índice de masa y composición corporal en personal activo del Ejército colombiano: un estudio de caso. Rev Científica Gen José María Córdova. 2018;16(22):93.

25. Durán-Agüero S, Maraboli Ulloa D, Fernández Frías F, Cubillos Schmied G. Composición corporal en soldados chilenos del Regimiento Buin. Rev Española Nutr Humana y Dietética. 2017;21(1):11.

26. Vázquez-Guzmán MA, Carrera-Rodríguez G, Durán-García AB G-OO. Correlación del índice de masa corporal con el índice de masa grasa para diagnosticar sobrepeso y obesidad en población militar. Rev Sanid Mil Mex. 2016;70:505-15.

27. Blacker SD, Horner FL, Brown PI, Linnane DM, Wilkinson DM, Wright A, et al. Health, Fitness, and Responses to Military Training of Officer Cadets in a Gulf Cooperation Council Country. Mil Med. 2013;176(12):1376-81. 